\title{
PERAN AKUN MEDIA SOSIAL BERBASIS KONTEN PARIWISATA PADA PENGAMBILAN KEPUTUSAN WISATAWAN UNTUK MENGUNJUNGI DESTINASI WISATA PADA ERA DIGITAL
}

\author{
Olivia Barcelona Nasution \\ STIE YKPN Yogyakarta \\ Email: oliviabarcelona@stieykpn.ac.id \\ Isnanda Zainur Rohman \\ STIE YKPN Yogyakarta \\ Email: Isnanda.zainur@stieykpn.ac.id
}

\begin{abstract}
Word of mouth evolved by the development of the internet. Besides offline word of mouth, online word of mouth, especially social media, is also on the rise. This study aims to examine the effect of online and offline word of mouth on the perceived destination image and the effect of the perceived image on the decision to visit a tourist destination. The number of respondents in this study were 148 people who were selected by purposive sampling technique. Hypothesis testing in this study uses multiple and simple linear regression using IBM SPSS 22 software. The results of this study are online and offline word of mouth have a positive effect on the perceived destination image and the perceived image also has a positive effect on tourists' decisions to visit tourist destinations.
\end{abstract}

Keywords: eWOM, WOM, perceived destination image, visit decision, tourist destination.

\section{Pendahuluan}

Pemasaran pariwisata sedang digalakkan oleh negara-negara di dunia, salah satunya Indonesia. Kegiatan pemasaran yang dilakukan pemerintah, salah satu diantaranya adalah dengan branding pariwisata, mulai dari Visit Indonesia hingga Wonderful Indonesia yang dicanangkan sejak tahun 2011. Banyak cara yang telah dilakukan oleh Kementerian Pariwisata untuk memasarkan pariwisata Indonesia, 
Peran Akun Media Sosial Berbasis Konten Pariwisata Pada Pengambilan Keputusan Wisatawan ...

baik dalam dan luar negeri. Salah satu upaya yang gencar dilakukan adalah memperkenalkan pariwisata Indonesia melalui dunia digital.

Pengembangan pariwisata tidak dapat hanya bertumpu pada pemerintah saja. Sudah banyak pihak yang turut membantu pengembangan pariwisata Indonesia. Hal ini ditunjukkan dengan meningkatnya akun-akun media sosial dengan konten yang berbasis pariwisata. Berbeda dengan akun sosial personal, akun media sosial dengan konten yang berbasis pariwisata akan lebih dapat dipercaya karena fokus akun ini tentunya berbeda dengan akun media sosial personal yang memiliki konten kurang terfokus.

Pemasaran pariwisata pada era digital ini salah satunya berasal dari konten media sosial berbasis pariwisata yang menjadi sumber informasi bagi para calon pengunjung. Hal ini karena banyak wisatawan yang membagikan pengalaman yang mereka rasakan ke media sosial (Sjaida et al., 2021). Salah satu media sosial yang paling banyak digunakan pengunjung dalam pencarian informasi destinasi wisata adalah Instagram. Instagram menjadi platform yang paling efektif untuk menyebarkan informasi pariwisata karena secara visual dapat menarik minat untuk mengetahui objek wisata di Indonesia (Kompas, 2015). Promosi pariwisata yang dilakukan secara digital sangat potensial karena dapat memengaruhi tingkat kunjungan pariwisata. Kementerian Pariwisata menyatakan sekitar 70 persen media digital berperan besar untuk penyebaran informasi destinasi wisata dan akomodasi wisata kepada para wisatawan (Travel Kompas, 2017). Banyak akun media sosial dengan konten pariwisata yang memiliki banyak pengikut, contohya akun instagram @indtravel dengan lebih dari 600 ribu pengguna, @exploreindonesia dengan pengikut sejumlah 300 ribuan, @indotravellers.co dengan pengikut lebih dari 700 ribu pengguna, @folkindonesia dengan jumlah pengikut 500 ribuan dan masih banyak lagi akun media sosial dengan konten berbasis pariwisata yang menjadi referensi wisatawan dalam memilih destinasi wisata tujuan mereka. 
Komunikasi dari mulut ke mulut atau dikenal dengan getok tular (word of mouth) dianggap sebagai sumber informasi yang paling bepengaruh dan dominan dalam mengembangkan citra destinasi (Beerli \& Martın, 2004). Adanya getok tular juga diyakini dapat mengurangi risiko dan ketidakpastian terkait barang dan jasa yang akan dibeli (Abubakar, 2016). Pada saat yang sama, perkembangan teknologi komunikasi elektronik telah menyebabkan munculnya getok tular elektronik (electronic word of mouth). Getok tular daring dianggap lebih efektif dibandingkan komunikasi getok tular luring karena aksesibilitas yang lebih besar serta jangkauannya yang lebih tinggi (Jalilvand, 2017). Meskipun sumber-sumber elektronik disukai banyak wisatawan, terutama konten dari media sosial pariwisata yang terkenal,sumber informasi ini dianggap kurang kredibel (Ishida et al., 2016). Oleh karena itu penting untuk mengidentifikasi kedua jenis getok tular, yaitu getok tular daring dan getok tular luring. Selain itu, belum banyak penelitian yang menguji getok tular daring dan luring dalam satu model penelitian. Sehingga penelitian ini diharapkan meberikan kontribusi praktis dan teoritis dalam dunia pemasaran.

Citra destinasi adalah faktor utama yang mempegaruhi pilihan destinasi wisatawan dan dianggap memiliki peran penting dalam proses pengambilan keputusan perjalanan wisatawan (Ishida et al., 2016). Citra destinasi terbentuk pada persepsian wisatawan melalui paparan sumber informasi (Tapachai \& Waryszak, 2000).

Ketika persepsian mengenai citra destinasi wisata yang baik terbentuk maka timbul perilaku penerimaan berupa keputusan untuk mengunjungi destinasi wisata. Hasil penelitian Mulyati, Haryeni, \& Masruri (2018) menunjukkan bahwa citra destinasi wisata berpengaruh pada keputusan untuk mengunjungi destinasi wisata. Hal ini karena citra yang positif akan selalu diingat dalam benak konsumen yang pada akhirnya akan menciptakan keputusan pembelian (Musay et al., 2013). 
Peran Akun Media Sosial Berbasis Konten Pariwisata Pada Pengambilan Keputusan Wisatawan ...

\section{Kajian Pustaka dan Perumusan Hipotesis}

Pemasaran pariwisata merupakan salah satu bidang yang diandalkan pemerintah Indonesia dalam rangka meningkatkan kesejahteraan negara dan masyarakat (Kemenpar, 2016). Salah satu faktor yang paling berpengaruh dalam pembelian produk (tujuan) wisata adalah informasi mengenai barang dan jasa wisata tersebut. Sumber informasi tentang tujuan wisata memiliki pengaruh yang besar pada proses pengambilan keputusan wisatawan dan perilaku wisatawan akan menetukan bagaimana pencarian informasi dilakukan dan bagaimana informasi akan digunakan (Molina et al., 2010). Dengan meningkatnya informasi positif tentang suatu destinasi wisata di media sosial, maka citra destinasi wisata tersebut akan turut meningkat di masyarakat (Paludi, 2017). Studi dalam pariwisata telah menunjukkan pengaruh getok tular yang tinggi pada citra destinasi dan pemilihan destinasi karena tingginya tingkat kredibilitas yang dirasakan atas sumber informasi yang didapatkan. getok tular mengacu pada pertukaran informasi tatap muka, tetapi telah berkembang menjadi bentuk getok tular yang lebih impersonal tetapi lebih meresap, yang disebut sebagai nilai getok tular elektronik atau getok tular daring (eWOM) yang berdasarkan kemajuan informasi teknologi dan meningkatnya akses ke Internet (Gonzales, 2016). Getok tular luring menggunakan media sosial merupakan salah satu strategi pemasaran yang dianggap efektif untuk meningkatkan pengunjung destinasi wisata (Wiryokusumo et al., 2021). Getok tular daring memiliki karakteristik mirip dengan getok tular luring (seperti saran teman, kerabat, atau pihak lain yang terdekat dan terpercaya) yang dianggap sebagai salah satu sumber informasi paling berpengaruh yang mendorong pembentukan citra, meskipun dalam getok tular daring, wisatawan tidak mengetahui orang yang menciptakan konten tersebut (Ring et al., 2014). Getok tular luring juga memiliki keunggulan, yaitu memiliki pengaruh yang lebih kuat pada tahap pengambilan keputusan karena dirasa lebih kredibel dibandingkan dengan getok tular daring (Ishida et al., 2016). Beberapa penelitian terdahulu menyebutkan bahwa getok tular berpengaruh citra destinasi wisata (Gonzales, 2016; Suwarduki, 
Yulianto, \& Mawardi, 2016; Jalilvand, 2017) dan penting untuk menguji kedua jenis getok tular ini ( getok tular daring dan luring) pada citra destinasi.

Citra destinasi tentu menjadi faktor penentu perilaku pembelian wisatawan. Citra yang dipersepsikan pengunjung akan mempengaruhi perilaku, kepuasan dan pengambilan keputusan mereka (Marine-roig \& Anton, 2016). Citra destinasi dapat didefinisikan sebagai keseluruhan dari kesan, keyakinan, ide, harapan, dan perasaan yang terakumulasi untuk menuju suatu tempat dari waktu ke waktu (Marine-roig \& Anton, 2016). Keputusan pembelian pada pariwisata terkait dengan kunjungan wisatawan pada destinasi wisata (P. R. Suwarduki et al., 2016). Kebutuhan untuk berwisata dipengaruhi oleh banyak faktor yang memotivasi wisatawan dalam pengambilan keputusan dalam menentukan tempat wisata yang akan dipilih. Salah satu alasan kenapa wisatawan berwisata adalah untuk melepaskan penat. Seseorang yang belum pernah mengunjungi tempat wisata tentunya akan melakukan pencarian informasi yang mungkin diawali dengan pencarian informasi dari lingkungan terdekat seperti keluarga, teman, dan kerabat lainnya atau bahkan pencarian informasi secara daring. Jika tercipta citra positif pada destinasi yang dituju tentunya akan menciptakan keputusan untuk mengunjungi tempat wisata tersebut. Penelitianpenelitian terdahulu membuktikan bahwa citra destinasi wisata berpengaruh positif terhadap keputusan untuk mengunjungi destinasi wisata (Musay et al., 2013; Illah, Romadhan, Sri, \& Rusmana, 2017).

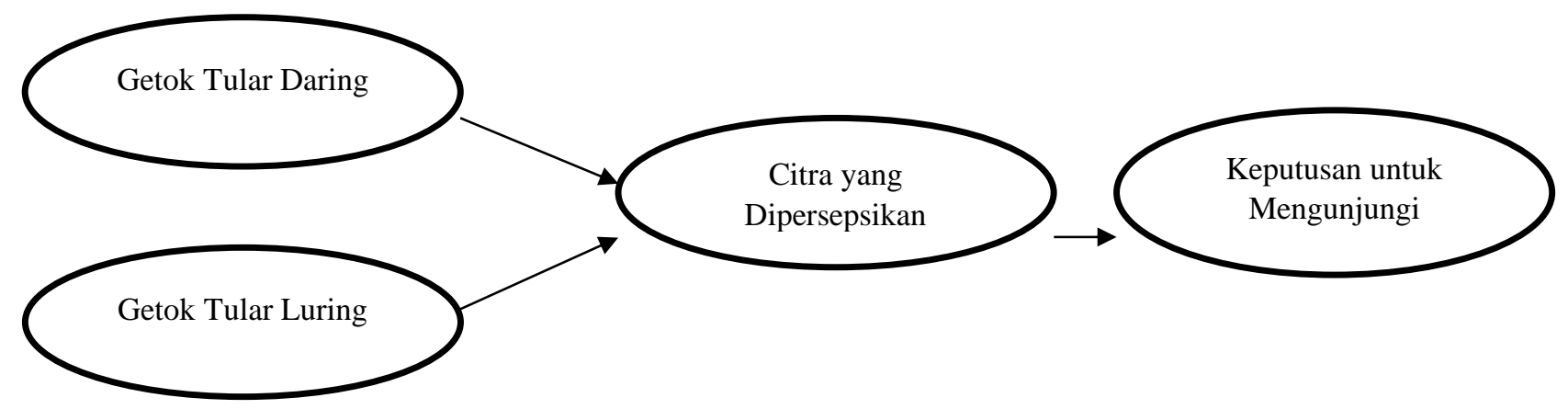

Gambar 1. Model Penelitian 
Peran Akun Media Sosial Berbasis Konten Pariwisata Pada Pengambilan Keputusan Wisatawan ...

Dari kajian pustaka di atas, maka dirumuskan hipotesis berikut ini:

H1: Getok tular daring berpengaruh terhadap citra yang dipersepsikan

H2: Getok tular luring berpengaruh terhadap citra yang dipersepsikan

H3: Citra yang dipersepsikan berpengaruh terhadap keputusan untuk mengunjungi destinasi wisata

\section{Metode Penelitian}

Jenis penelitian yang diterapkan dalam penelitian ini adalah penelitian eksplanatori dengan menguji hipotesis yang telah dirumuskan. Pengumpulan data dilakukan dengan survei. Variabel yang diuji dalam penelitian ini adalah getok tular elektronik, citra yang dipersepsikan, dan keinginan untuk mengunjungi destinasi wisata. Survei dilakukan dengan menyebarkan kuesioner yang berisi item-item pertanyaan yang diadopsi dari penelitian terdahulu. Getok tular elektronik diukur dengan item-item yamg diadopsi dari penelitian Ishida et al. (2016). Citra yang dipersepsikan diukur dengan item-item kuesioner yang diadopsi dari penelitian Jalilvand (2017). Keputusan mengunjungi destinasi wisata diukur dengan item-item yang diadopsi dari penelitian Mulyati et al. (2018) . Skala yang digunakan dalam penelitian ini adalah 5 (lima) skala Likert dengan pilihan Sangat Tidak Setuju (1) sampai dengan Sangat Setuju (5).

Teknik pengambilan sampel yang digunakan dalam penelitian ini adalah purposive sampling yaitu memilih sampel atas dasar penilaian karakteristik sampel yang sesuai dengan tujuan penelitian (Kuncoro, 2009). Data yang digunakan dalam penelitian ini adalah data primer yang diperoleh dengan penyebaran kuesioner yang berisi item-item pertanyaan yang diadopsi dari penelitian- penelitian terdahulu. Kriteria sampel untuk penelitian ini yaitu responden yang mengunjungi tempat wisata setelah mencari referensi melalui akun media sosial dengan konten berbasis 
pariwisata dalam satu tahun terakhir. Jumlah sampel yang baik menurut Hair et al. (2010) adalah 5 hingga 10 kali dari jumlah item dalam kuesioner penelitian.

Pengujian awal yang dilakukan adalah uji validitas untuk mengetahui apakah item-item yang digunakan dalam penelitian ini memang mengukur apa yang seharusnya diukur (Kuncoro, 2009). Pengujian validitas yang digunakan adalah uji validitas konstruk dengan berdasarkan uji validitas konvergen. Pengujian validitas konvergen yang baik ditunjukkan dengan indikator-indikator dari suatu konstruk yang mengumpul pada suatu kelompok tertentu. Umumnya, item-item pada konstruk tersebut memiliki nilai factor loading $\geq 0,5$. Sebelum menguji validitas konvergen dengan melihat factor loading, ada persyaratan yang harus dipenuhi terlebih dahulu yaitu uji Kaiser-Meyer-Olkin Measute of Sampling Adequacy (KMO MSA). Nilai syarat untuk KMO MSA > 0,5, sedangkan untuk Barlett's Test of Sphericity yaitu signifikan <0,05 (Hair et al., 2010).

Pengujian selanjutnya yang dilakukan adalah uji reliabilitas untuk mengetahui item-item pengukuran dalam penelitian ini konsisten atau tidak dalam mengukur konstruk yang akan diukur (Hair et al., 2010). Konsistensi dari jawaban responden dilihat dari nilai Cronbach's Alpha. Nilai batasan Cronbach's Alpha agar konstruk dikatakan reliabel yaitu >0,7, akan tetapi, Hair et al., (2010) myenebutkan bahwa nilai 0,6 masih dapat diterima. Selanjutnya, peneliti menguji hipotesis menggunakan simple dan multiple regression analysis dengan menggunakan IBM SPSS versi 22.

\section{Hasil Penelitian dan Pembahasan}

Kuesioner dibagikan kepada responden yang pernah mengunjungi destinasi wisata dalam enam bulan terakhir. Pada Tabel 1, dapat dilihat bahwa mayoritas responden berjenis kelamin perempuan (54,7 \%) dengan rentang usia 19 - 24 tahun. Pendidikan terakhir mayoritas responden adalah sarjana (S1) dengan pekerjaan sebagai mahasiswa. 
Peran Akun Media Sosial Berbasis Konten Pariwisata Pada Pengambilan Keputusan Wisatawan ...

Sebelum melakukan pengujian hipotesis, peneliti menguji validitas dan reliabilitas kuesioner dari data yang telah didapatkan. Dari Tabel 2, dapat dilihat bahwa semua item kuesioner dalam penelitian ini valid karena memiliki factor loading $>0,5$. Selain itu, dari hasil pengujian reliabilitas juga dapat disimpulkan bahwa semua item kuesioner yang dipakai reliabel karena memiliki nilai Cronbach's Alpha > 0,6.

Tabel 1. Demografi Responden

\begin{tabular}{|c|c|c|c|}
\hline Karakteristik & Kategori & Jumlah & Persentase \\
\hline Jenis & Laki-laki & 67 & 45,3 \\
\hline Kelamin & Perempuan & 81 & 54,7 \\
\hline \multirow{5}{*}{ Usia } & $0-18$ & 10 & 6,8 \\
\hline & $19-24$ & 95 & 64,2 \\
\hline & $25-34$ & 37 & 25 \\
\hline & $35-44$ & 4 & 2,7 \\
\hline & $\geq 45$ & 2 & 1,4 \\
\hline \multirow{5}{*}{ Pendidikan } & SD/SMP/SMA & 22 & 14,9 \\
\hline & Diploma & 8 & 5,4 \\
\hline & Sarjana (S1) & 95 & 64,2 \\
\hline & Magister (S2) & 21 & 14,2 \\
\hline & Doktoral (S3) & 2 & 1,4 \\
\hline \multirow{7}{*}{ Pekerjaan } & Mahasiswa & 75 & 50,7 \\
\hline & Ibu Rumah Tangga & 2 & 1,4 \\
\hline & Pegawai Operasional & 23 & 15,5 \\
\hline & Pegawai Manajerial & 13 & 8,8 \\
\hline & Profesional (Pengacara, Atlet, dll) & 3 & 2 \\
\hline & Wiraswasta/wirausaha & 18 & 12,2 \\
\hline & Lainnya & 14 & 9,5 \\
\hline \multirow{5}{*}{ Pengeluaran } & $<1.000 .000$ & 37 & 25 \\
\hline & $1.000 .001-2.500 .000$ & 67 & 45,3 \\
\hline & $2.500 .001-5.000 .000$ & 33 & 22,3 \\
\hline & $5.000 .001-10.000 .000$ & 7 & 4,7 \\
\hline & $>10.000 .000$ & 4 & 2,7 \\
\hline
\end{tabular}


Tabel 2. Uji Validitas, dan Reliabilitas

\begin{tabular}{|c|c|c|c|c|c|}
\hline \multirow{2}{*}{ Item Kuesioner } & \multicolumn{4}{|c|}{ Loading Factor } & \multirow{2}{*}{$\begin{array}{l}\text { Cronbach's } \\
\text { Alpha }\end{array}$} \\
\hline & 1 & 2 & 3 & 4 & \\
\hline \multicolumn{6}{|c|}{ Getok Tular Daring } \\
\hline $\begin{array}{l}\text { Saya merasa lebih nyaman mengunjungi } \\
\text { destinasi wisata ketika saya mendapatkan } \\
\text { opini perjalanan daring (online) dari media } \\
\text { sosial berkonten pariwisata. }\end{array}$ & 0.75 & & & & \multirow{3}{*}{0.618} \\
\hline $\begin{array}{l}\text { Ketika saya mempertimbangkan untuk } \\
\text { mengunjungi destinasi wisata, saya } \\
\text { mencari ulasan secara daring dari media } \\
\text { sosial berkonten pariwisata }\end{array}$ & 0.78 & & & & \\
\hline $\begin{array}{l}\text { Opini dari media sosial berkonten } \\
\text { pariwisata memengaruhi pilihan destinasi } \\
\text { wisata saya. }\end{array}$ & 0.62 & & & & \\
\hline \multicolumn{6}{|c|}{ Getok Tular Luring } \\
\hline $\begin{array}{l}\text { Saya merasa lebih nyaman mengunjungi } \\
\text { destinasi wisata ketika saya mendapat } \\
\text { opini dari orang yang saya kenal secara } \\
\text { langsung }\end{array}$ & & 0.84 & & & \multirow{3}{*}{0.764} \\
\hline $\begin{array}{l}\text { Ketika saya mempertimbangkan untuk } \\
\text { mengunjungi destinasi wisata, saya } \\
\text { meminta pendapat dan nasihat orang lain } \\
\text { secara langsung. }\end{array}$ & & 0.81 & & & \\
\hline $\begin{array}{l}\text { Komunikasi tatap muka dengan orang } \\
\text { yang saya kenal memengaruhi pilihan } \\
\text { destinasi wisata saya. }\end{array}$ & & 0.65 & & & \\
\hline \multicolumn{6}{|c|}{ Citra yang Dipersepsikan } \\
\hline $\begin{array}{l}\text { Menurut saya, destinasi wisata yang } \\
\text { terdapat dalam media sosial berkonten } \\
\text { pariwisata sangat menarik }\end{array}$ & & & 0.65 & & \multirow{3}{*}{0.837} \\
\hline $\begin{array}{l}\text { Menurut saya, destinasi wisata yang } \\
\text { terdapat dalam media sosial berkonten } \\
\text { pariwisata sangat menyenangkan }\end{array}$ & & & 0.79 & & \\
\hline $\begin{array}{l}\text { Menurut saya, destinasi wisata yang } \\
\text { terdapat dalam media sosial berkonten } \\
\text { pariwisata sangat nyaman }\end{array}$ & & & 0.78 & & \\
\hline
\end{tabular}


Peran Akun Media Sosial Berbasis Konten Pariwisata Pada Pengambilan Keputusan Wisatawan ...

\begin{tabular}{|c|c|c|c|c|c|}
\hline \multirow{2}{*}{ Item Kuesioner } & \multicolumn{4}{|c|}{ Loading Factor } & \multirow{2}{*}{$\begin{array}{l}\text { Cronbach's } \\
\text { Alpha }\end{array}$} \\
\hline & 1 & 2 & 3 & 4 & \\
\hline \multicolumn{6}{|c|}{ Keputusan untuk Mengunjungi } \\
\hline $\begin{array}{l}\text { Setelah melihat konten pariwisata di } \\
\text { media sosial, saya berencana } \\
\text { mengunjungi destinasi tersebut }\end{array}$ & & & & 0.79 & \multirow{3}{*}{0.852} \\
\hline $\begin{array}{l}\text { Setelah melihat konten pariwisata di } \\
\text { media sosial, saya akan mengunjungi } \\
\text { destinasi tersebut }\end{array}$ & & & & 0.83 & \\
\hline $\begin{array}{l}\text { Setelah melihat konten pariwisata di } \\
\text { media sosial, saya memutuskan untuk } \\
\text { mengunjungi destinasi tersebut }\end{array}$ & & & & 0.82 & \\
\hline
\end{tabular}

Tabel 3. Hasil Pengujian Kesesuaian Model pada Regresi Variabel

Getok Tular Daring dan Getok Tular Luring pada Citra yang Dipersepsikan

\begin{tabular}{lrrr}
\hline \multicolumn{1}{c}{ Variabel Independen } & $\boldsymbol{\beta}$ & $\mathbf{t}$ & sig. \\
\hline Getok Tular Daring & 0.178 & 2.534 & 0.012 \\
Getok Tular Luring & 0.517 & 0.517 & 0.000 \\
\hline Adjusted R2 & 0.348 & & \\
F & 40.226 & & \\
Sign & 0.000 & & \\
\hline
\end{tabular}

Hipotesis yang diuji dalam penelitian ini adalah pengaruh getok tular daring dan luring terhadap citra yang dipersepsikan serta pengaruh citra yang dipersepsikan terhadap keputusan untuk mengunjungi destinasi wisata. Semua hipotesis yang diuji dalam penelitian ini diterima. Hasil pengujian hipotesis dapat dilihat pada Tabel 3 dan Tabel 4.

Hasil pengujian hipotesis menunjukkan bahwa getok tular daring $(\beta=0.178)$ dan getok tular daring $(\beta=0.517)$ berpengaruh positif dan signifikan terhadap citra yang dipersepsikan $(\mathrm{p}<0.05)$. Hasil penelitian ini sejalan dengan beberapa penelitian 
terdahulu (Atika et al., 2017; Jalilvand, 2017; Mulyati et al., 2018; Prayogo \& Kusumawardhani, 2016; P. Suwarduki et al., 2016). Getok tular daring dan luring sama-sama memiliki peran penting sebagai agen pemasaran, dimana getok tular yang dilakukan menjadi sarana penyebaran informasi kepada calon konsumen atau calon pengunjung destinasi wisata. Perbedaan antara getok tular daring dan luring terletak pada sebaran informasi dan kepercayaan calon pengunjung terhadap informasi yang disebarkan. Getok tular daring dilakukan menggunakan media internet seperti blog, media sosial atau platform lain untuk menyebarkan foto dan video yang membuat sebaran informasi menjadi lebih luas. Akan tetapi, adanya faktor anonimus atau penyebar informasi daring (dalam konteks penelitian ini adalah pemilik akun media social yang berbasis konten pariwisata) yang tidak dikenal membuat informasi yang disebarkan menimbulkan keraguan atas validitas informasi yang disampaikan.

Tabel 4. Hasil Pengujian Kesesuaian Model pada Regresi Variabel Citra yang Dipersepsikan pada Keputusan untuk Mengunjungi

\begin{tabular}{llll}
\hline \multicolumn{1}{c}{$\begin{array}{c}\text { Variabel } \\
\text { Independen }\end{array}$} & $\boldsymbol{\beta}$ & $\mathbf{t}$ & sig. \\
\hline $\begin{array}{l}\text { Citra yang } \\
\text { Dipersepsikan }\end{array}$ & 0.589 & 8.807 & 0.000 \\
\hline Adjusted R2 & 0.342 & & \\
F & 77.57 & & \\
Sign & 0.000 & \\
\hline
\end{tabular}

Berbeda dengan getok tular daring, getok tular luring dilakukan secara langsung tanpa adanya media. Penyebaran informasi secara luring tidak seluar daring. Akan tetapi, kualitas informasi yang disampaikan lebih mudah untuk dipercayai oleh calon pengunjung. Hal yang sama disampaikan oleh Ishida et al. (2016), getok tular daring menjangkau lebih luas dan cepat karena diarahkan pada banyak individu, serta tersedia kapan saja. Pada akhirnya tidak dapat dihindarkan 
Peran Akun Media Sosial Berbasis Konten Pariwisata Pada Pengambilan Keputusan Wisatawan ...

bahwa kedua jenis getok tular ini sangat penting dalam mengembangkan citra destinasi wisata.

Tabel 4 menunjukkan bahwa citra yang dipersepsikan $(\beta=0.589)$ berpengaruh positif dan signifikan terhadap keputusan untuk mengunjungi destinasi wisata $(\mathrm{p}<$ 0.05). Hasil penelitian ini sejalan dengan beberapa penelitian terdahulu (Diposumarto et al., 2015; Isnaini \& Abdillah, 2018; Setyaningsih, 2017; Wulandari, 2013). Calon wisatawan memiliki penilaian sendiri setelah melakukan pencarian gambar dan informasi melalui banyak media, salah satunya melalui media sosial yang memiliki konten berbasis pariwisata. Ketika calon wisatawan memiliki persepsi bahwa destinasi wisata tersebut memiliki pemandangan yang bagus dan nyaman untuk dikunjungi, hal ini semakin meningkatkan keinginan konsumen untuk langsung mengunjungi destinasi wisata yang telah dipilih.

\section{Kesimpulan dan Saran}

Getok tular daring dan luring merupakan cara pemasaran terbaik, terutama untuk pemasaran industri pariwisata. Hal ini karena pemasaran melalui getok tular tidak membutuhkan biaya yang terlalu besar, jangkauan yang lebih luas serta calon konsumen lebih mempercayai informasi yang disampaikan pihak ketiga dibandingkan dengan pengelola destinasi wisata atau pemerintah daerah. Calon wisatawan yang terpapar getok tular akan membentuk persepsi mengenai citra destinasi wisata sebelum berkunjung. Jika calon wisatawan memiliki persepsi yang baik, tentunya mereka akan langsung membuat keputusan untuk mengunjungi destinasi wisata tersebut, misalnya dengan memutuskan untuk melakukan kunjungan pada hari libur tertentu. Oleh karena itu, informasi mengenai destinasi wisata sangat penting untuk disebarluaskan, sehingga banyak wisatawan termasuk wisatawan asing semakin banyak yang mengunjungi destinasi wisata Indonesia. Para pengelola destinasi wisata dan pemerintah daerah atau provinsi juga dapat bekerja sama dengan para pemilik akun media sosial dengan konten berbasis pariwisata 
untuk turut serta mempromosikan destinasi wisata yang mereka miliki agar lebih dikenal banyak orang dan memudahkan pencarian dengan membuat kampanye hashtag pada media sosial tersebut.

Penelitian selanjutnya diharapkan dapat melengkapi penelitian ini. Penelitian mendatang dapat melakukan pengujian untuk membandingkan mana yang lebih memberikan pengaruh antara getok luring atau daring (Ishida et al., 2016). Selain itu, citra destinasi wisata dapat berperan sebagai variabel pemediasi antara getok tular dan perilaku pengunjung destinasi wisata (Atika et al., 2017) dan juga dapat dibedakan menjadi citra kognitif dan citra afektif (Yacoub \& Hamouda, 2018). Peneliti juga dapat melakukan komparasi antara wisatawan lokal dan mancanegara (Rohman \& Nasution, 2019).

\section{Ucapan Terima Kasih}

Penulis mengucapkan terima kasih kepada Kementerian Riset dan Teknologi atas bantuan pendanaan penelitian yang diberikan kepada penulis untuk skema Penelitian Dosen Pemula (PDP) pada tahun pelaksanaan 2020.

\section{Daftar Pustaka}

Abubakar, A. M. (2016). Does eWOM influence destination trust and travel intention : a medical tourism perspective. Economic Research-Ekonomska Istraživanja, 29(1), 1-14. https://doi.org/10.1080/1331677X.2016.1189841

Atika, A., Kusumawati, A., \& Iqbal, M. (2017). the Effect of Electronic Word of Mouth, Message Source Credibility, Information Quality on Brand Image and Purchase Intention. EKUITAS (Jurnal Ekonomi Dan Keuangan), 20(1), 94. https://doi.org/10.24034/j25485024.y2016.v20.i1.1780

Beerli, A., \& Martın, J. D. (2004). FACTORS INFLUENCING DESTINATION IMAGE. 31(3), 657-681. https://doi.org/10.1016/j.annals.2004.01.010

Diposumarto, N. S., Purwanto, W., \& Ramdan, I. (2015). Analysis of Tourism Destination Image and Promotion through Social Media Towards Purchasing 
Decision for Bali Tourism Product by Foreign Tourist. Mediterranean Journal of Social Sciences, 6(5), 175-182. https://doi.org/10.5901/mjss.2015.v6n5s5p175

González-Rodríguez, M. R., Martínez-Torres, R., \& Toral, S. (2016). Post-visit and previsit tourist destination image through eWOM sentiment analysis and perceived helpfulness. International Journal of Contemporary Hospitality Management, 28(11), 2609-2627.

Hair, J. F., Black, W. C., Babin, B. J., \& Anderson, R. E. (2010). Multivariate Data Analysis. Vectors. https://doi.org/10.1016/j.ijpharm.2011.02.019

Illah, A. N., Romadhan, M. I., Sri, D., \& Rusmana, A. (2017). Potensi Media Sosial Sebagai Sarana Media Promosi Pariwisata Berbasis Partisipasi Masyarakat. 85-90.

Instagram.Efektif.Menyebarkan.Informasi.Pariwisata. (2015).

https://ravel.kompas.com/read/2015/07/04/0916000/Instagram.Efektif.Menyeb arkan.Informasi.Pariwisata

Ishida, K., Slevitch, L., \& Siamionava, K. (2016). administrative sciences The Effects of Traditional and Electronic Word-of-Mouth on Destination Image: A Case of Vacation Tourists Visiting Branson, Missouri. https://doi.org/10.3390/admsci6040012

Isnaini, P. R., \& Abdillah, Y. (2018). Pengaruh Citra Merek Destinasi Terhadap Keputusan Berkunjung dan Kepuasan Serta Dampaknya Pada Minat Kunjungan (Survei pada Pengunjung Taman Rekreasi Selecta Kota Batu yang termasuk dalam Kategori Generasi Millennial). Jurnal Administrasi Bisnis (JAB), 5(2), 122-129.

Jalilvand, M. R. (2017). Word-of-mouth vs. mass media: their contributions to destination image formation. Anatolia, 28(2), 151-162. https://doi.org/10.1080/13032917.2016.1270840

Kuncoro, M., Widodo, T., \& McLeod, R. (2009). Survey of recent developments. Bulletin of Indonesian Economic Studies,45(2), 151-176. https://doi.org/10.1080/00074910903040302

Marine-roig, E., \& Anton, S. (2016). Journal of Destination Marketing \& Management Perceived image specialisation in multiscalar tourism destinations. Journal of Destination Marketing $\mathcal{E} \quad$ Management, 5(3), 202-213. https://doi.org/10.1016/j.jdmm.2015.12.007

Menpar: Promosi Digital Pengaruhi Kunjungan Wisatawan. (1 Agustus 2019).

Diperoleh dari

https://ravel.kompas.com/read/2015/05/01/175200927/Menpar.Promosi.Digita 1.Pengaruhi.Kunjungan.Wisatawan

Molina, A., Gómez, M., \& Martín-consuegra, D. (2010). Tourism marketing information and destination image management. 4(May), 722-728. 
Mulyati, Y., Haryeni, \& Masruri. (2018). Jurnal ekonomi E bisnis dharma andalas. 20(1), 168-187.

Musay, F. P., Administrasi, F. I., Brawijaya, U., Pemakai, C., Perusahaan, C., \& Pemakai, C. (2013). Pengaruh brand image terhadap keputusan pembelian.

Paludi, S. (2017). Analisis Pengaruh Electronic Word Of Mouth (EWom) terhadap Citra Destinasi, Kepuasan Wisatawan, Dan Loyalitas DestinasiPerkampungan Budaya Betawi (PBB) Setu Babakan Jakarta Selatan. Jurnal STEIN, 11(1).

Prayogo, R. R., \& Kusumawardhani, A. (2016). Examining Relationships of Destination Image, Service Quality, e-WOM, and Revisit Intention to Sabang Island, Indonesia. Asia Pacific Management and Business Application, 5(2), 85-96. https://doi.org/10.21776/ub.apmba.2016.005.02.3

Promosi Digital Web Travel, Sebuah Media Yang Efektif Meningkatkan Wisatawan. (2017). https://berjalanjalan.com/2015/10/09/promosi-digital-web-travelsebuah-media-yang-efektif-meningkatkan-wisatawan/.

Ring, A., Tkaczynski, A., \& Dolnicar, S. (2014). Word-of-Mouth Segments: Online, Offline, Visual or Verbal ? https://doi.org/10.1177/0047287514563165

Rohman, I. Z., \& Nasution, O. B. (2019). Persepsi Kualitas Layanan Pengunjung Candi Prambanan (Studi Komparasi Wisatawan Lokal dan Mancanegara). Upajiwa Dewantara: Jurnal Ekonomi, Bisnis dan Manajemen Daulat Rakyat, 3(2), 67-77.

Setyaningsih, S., \& Ekonomi, F. (2017). Pengaruh Motivasi, Promosi Dan Citra Destinasi Pada Kepuasan Pengunjung Melalui Keputusan Pengunjung. Management Analysis Journal, 6(2). http://maj.unnes.ac.id

Sjaida, Gheya Madinatu; Khadijah, Ute Lies Siti; Novianti, Evie. Stragtegi Komunikasi Pariwisata Taman Air Mancur Sri Baduga Melalui Media Instagram @Urangpurwakarta. Jurnal Master Pariwisata (JUMPA), [S.1.], p. 386 - 410, jan. 2021. ISSN 2502-8022.

Suwarduki, P. R., Yulianto, E., \& Mawardi, M. K. (2016). PENGARUH ELECTRONIC WORD OF MOUTH TERHADAP CITRA DESTINASI SERTA DAMPAKNYA PADA MINAT DAN KEPUTUSAN BERKUNJUNG (Survei pada Followers Aktif Akun Instagram Indtravel yang Telah Mengunjungi Destinasi Wisata di Indonesia ). 37(2), 1-10.

Suwarduki, P., Yulianto, E., \& Mawardi, M. (2016). PENGARUH ELECTRONIC WORD OF MOUTH TERHADAP CITRA DESTINASI SERTA DAMPAKNYA PADA MINAT DAN KEPUTUSAN BERKUNJUNG (Survei pada Followers Aktif Akun Instagram Indtravel yang Telah Mengunjungi Destinasi Wisata di Indonesia). Jurnal Administrasi Bisnis S1 Universitas Brawijaya, 37(2), 1-10.

Tapachai, N., \& Waryszak, R. (2000). An Examination of the Role of Beneficial Image in Tourist. https://doi.org/10.1177/004728750003900105 
Thara, N., Zainal, A., Harun, A., \& Lily, J. (2017). Asia Paci fi c Management Review Examining the mediating effect of attitude towards electronic words-of mouth $(\mathrm{eWOM})$ on the relation between the trust in eWOM source and intention to follow eWOM among Malaysian travellers, 22.

Wiryokusumo, Monica Yohana Putri; Wiranatha, Agung Suryawan; Suryawardani, I Gusti Ayu Oka. Pengaruh Electronic Word of Mouth (EWOM) Terhadap Brand Image, Trust dan Keputusan Berkunjung ke Kampung Tridi Malang. Jurnal Master Pariwisata (JUMPA), [S.1.], p. 332 - 350, july 2021. ISSN 2502-8022.

Wulandari, T. (2013). Analisis Place Branding untuk Meningkatkan Citra Kabupaten Purwakarta serta Implikasinya terhadap Keputusan Mengunjungi Destinasi Pariwisata (Survei terhadap Wisatawan Nusantara yang Berkunjung ke Kabupaten Purwakarta). Jurnal Ilmu Manajemen Dan Bisnis, 4(2), 1-12. https://doi.org/10.17509/jimb.v4i2.1008

Yacoub, I., \& Hamouda, M. (2018). Explaining visit intention involving eWOM, perceived risk motivations and destination image. International Journal of Leisure and Tourism Marketing, 6(1), 65. https://doi.org/10.1504/ijltm.2018.10009971

\section{Profil Penulis}

Olivia Barcelona Nasution merupakan dosen Prodi S1 Manajemen di STIE YKPN Yogyakarta. Riwayat pendidikan yang pernah ditempuh adalah menyelesaikan pendidikan S1 di Universitas Riau pada tahun 2014 dan menyelesaikan S2 di Universitas Gadjah Mada pada tahun 2017. Fokus penelitian beliau adalah manajemen pemasaran.

Isnanda Zainur Rohman merupakan dosen Prodi S1 Manajemen di STIE YKPN Yogyakarta. Riwayat pendidikan yang pernah ditempuh adalah menyelesaikan pendidikan S1 di STIE YKPN Yogyakarta pada tahun 2015 dan menyelesaikan S2 di STIE YKPN Yogyakarta pada tahun 2017. Fokus penelitian beliau adalah manajemen pemasaran. 